\title{
The appreciation of artistic aspects of the Code of Points in rhythmic gymnastics: an analysis of the last three decades
}

CDD. 20.ed. 796.41

http://dx.doi.org/10.1590/1807-55092016000100119
Eliana de TOLEDO*

Kizzy ANTUALPA******

\begin{abstract}
In pursuit of promoting the artistic aspects, the current Rhythmic Gymnastics Code of Points (RGCP) has been submeted significant changes that motivated this research, documentary and historical in character, which aimed to analyze the last eight Olympic cycles of RGCP. The research method used in this study is documentary and characterized by the information found in documents (RGCP) that had not received any scientific treatment. From the analysis of different RGCP cycles, we found artistic aspects, and their connection with RG technical requirements. We observed that the RG has distinct stages (technical aspects, flexibility etc). While retaining its artistic roots (from Dance and Rhythm), in pursuit of sportivization and systematization of the sport, the first stage was characterized by a search for the sportivization and standardization of the modality based on the inclusion of new body elements in the RGCP. The second stage confirms our previous hypothesis, that in the last RGCP the artistic component had undergone few changes. We noticed, in an overview, that at the present time the current RGCP brings back the relationship between RG and its origins, influenced by Aesthetic Gymnastics (Swedish), Rhythmic and Dance. Condition observed once the current Code of Points (2013-2016) marks the story of sports, by two aspects: the permissiveness of routines with singing wich has not allowed since since the creation the RGCP and significant changes to the appreciation of the routines' artistic aspects.
\end{abstract}

KeY WoRDS: Aesthetics; Artistic; Technique; Composition; Gymnastics; Routines.

\section{Introduction}

Rhythmic Gymnastics (RG), since its sport consolidation as a gymnastics area by the International Gymnastics Federation (FIG), has gone through different changes both in its name and in its evaluation.
Concerning its nomenclature, a group of authors has published its modifications chronologically, highlighting, according to LANGLADE and LANGLADE $^{1}$, BODO-SCHMID ${ }^{2}$ and BOBO and SIERRA ${ }^{3}$ :

TABLE 1 - Modifications of the rhythmic gymnastics nomenclatures.

\begin{tabular}{ll}
\hline Year & \multicolumn{1}{c}{ Modification } \\
\hline 1970 & $\begin{array}{l}\text { The first publication of Modern Gymnastics Code of Points, distinguishing this sport from the known } \\
\text { Olympic Gymnastics (currently Artistic Gymnastics). }\end{array}$ \\
1972 & $\begin{array}{l}\text { The Modern Gymnastics officially legitimized as a sport organized by FIG, and named Modern Rhythmic } \\
\text { Gymnastics. }\end{array}$ \\
1975 & FIG established this modality as Rhythmic Sport Gymnastics. \\
2000 & FIG established this modality as Rhythmic Gymnastics.
\end{tabular}


The initially non-competitive nature of Modern Gymnastics contemplated an aesthetic and practical fitness, linked to the Swedish method ${ }^{1,4}$, that from the international literature in the field, has listed some influences that RG suffered before becoming a sport:

- Influence of Jean Georges Noverre (late eighteenth century), master of French dancing, which method/proposal was based on natural movements, with an emphasis on "art of expressing";

- Influence of François Delsarte, drama actor, who emphasized the postures and the spiritual condition of the student, and the relationship between them as the essence of expressive movement;

- Influence of dance teachers Rudolf von Laban, Isadora Duncan and Elizabeth Duncan, on expressiveness and choreography;

- Influence of Expressive Gymnastics, which refuses improvised movements, uses strength as one of the fundamental capabilities;

- Emile Jacques Dalcroze, French composer and teacher who defines Modern Gymnastics, enhancing the musical and rhythmic characteristics;

- Rudolf Bode systematizes RG, through the elements of dance, theater, music, pedagogy, also using manual instruments as bats, balls and drums;

- Henrich Medau completes this designation, systematizing it with manual instruments such as rope and hoops.

However, under the aegis of the FIG, Modern Gymnastics followed the path of other practices towards a universal regulatory process by means of a worldwide institution, becoming a sport ${ }^{5-6}$, constituting itself as a way of collective identification and as a source of meaning in people's lives, being a carrier of a pleasant excitement ${ }^{7}$.

In this context, as a sport, RG becomes regulated in 1970, having a set of rules that guide the evaluation techniques of the gymnasts, and therefore the training methods and composition of routines. This regulation is elaborated by the FIG RG Technical Committee ${ }^{8}$, which is adjusted every four years (Olympic cycle).
Since 1970 to the present, the RGCP has already gone through 13 versions or cycles:

TABLE 2 - Code of Points cycles of rhythmic gymnastics.

\begin{tabular}{lc}
\hline Cycle & Years \\
\hline 1st cycle & $1970-1971$ \\
2nd cycle & $1971-1972$ \\
3rd cycle & $1973-1976$ \\
4th cycle & $1977-1980$ \\
5 th cycle & $1981-1984$ \\
6th cycle & $1985-1988$ \\
7th cycle & $1989-1992$ \\
8th cycle & $1993-1996$ \\
9th cycle & $1997-2000$ \\
10th cycle & $2001-2004$ \\
11th cycle & $2005-2008$ \\
12th cycle & $2009-2012$ \\
13th cycle & $2013-2016$ \\
\hline
\end{tabular}

LOURENÇO9 emphasizes that the changes in the regulation of RG not only occur from one cycle to another, but also within the four-year period that each of them contains. According to the author: [...] RG still has a big problem to be solved, which is the question related to the duration of the rules. The Code is organized, at first, to last four years, but changes take place annually, with the systematic production of "letters" that present clarifications, but also, many changes in criteria and minor adjustments in the rules that hinder the understanding of referees and a lighter assessment. The "letters" also bring the originality of the year and new difficulties created and already granted by the FIG Technical Committee. We realize that gymnasts and especially coaches are concerned with always staying alert to changes, in order to enhance their compositions without running the risk of unnecessary prejudice. 
In the last code cycle (2013-2016) ${ }^{10}$, there was an increased appreciation of the artistic aspects. From our experience as researchers, former coaches/trainers and judges, this situation has set a RG specific sport improvement. As in the last cycles, greater attention to technical aspects was given, featuring the routines such as sequences of elements, more than choreographic compositions with artistic imprint.

This perception configured the hypothesis that originated this research, which aims to recognize and analyze the ways of promoting artistic aspects in the Rhythmic Gymnastics Code of Points in the last eight cycles (three decades). Justified by the contemplation of this gap in the scientific

\section{Method}

This research used the documentary method, which is characterized by the information found in documents that have not received any scientific treatment, such as reports, newspaper articles, magazines, letters, films, recordings, photographs, and other communications materials ${ }^{16}$.

The documentary sources of the research were composed of eight cycles of Rhythmic Gymnastics Code of Points (RGCP), from 1985 to the present, involving (according to TABLE 2) specifically the periods of: 1985-1988; 1989-1992; 1993-1996; 1997-2000; 2001-2004; 2005-2008; 2009-2012; and 2013-2016. The first stage covers the first three Olympic cycles (1985-1988; 1989-1992; and 19931996), and has the presence of individual competitions at the Olympic Games (OG). The second stage covers the other cycles (1997-2000; 2001-2004; 2005-2008; 2009-2012; and 2013-2016) and has the participation of individual gymnasts and groups in OG.

\section{Results e discussion}

The routine in Rhythmic Gymnastics is guided by the evaluation of three important issues concerning the aspects of execution and sphere, around the analysis of the RGCP (past and present), this research glimpses to contribute towards a historical analysis of the sport (through its regulations). But as well as towards reflection and action, at the present time, by federal managers and others involved with the area in order to legitimize $\mathrm{RG}$ as a sport with an artistic nature (respecting its origins). Toledo ${ }^{11}$ and VELARDI ${ }^{12}$ underline the importance of valuing the artistic character in RG, not only in different educational contexts (formal and informal), but also for the Code of Points itself, since at any level of learning, artistic character / aesthetic can not be forgotten, or even left in the background $^{13-15}$

This time frame was established by the definition of four decades of RGCP study, without considering almost the first decade and a half of its existence (1970-1984), because it was characterized as a structuring stage of RG as a sport organized by the FIG (with different manifestations of the then Olympic Gymnastics).

These documents typically provide information about the topic of the research and are available on sites such as the International Gymnastics Federation $(\mathrm{FIG})^{8}$ and other sites of global organizations that promote gymnastics, like Gimnica (virtual Library) ${ }^{17}$, in English and French. Some cycles/ versions in print were obtained in LAPEGI's acquis - Laboratory Research and Experiments (FCA-Unicamp), in Spanish and Portuguese, which were used in judges courses of the Brazilian Confederation of Gymnastics. Analyses were made in the period from January to September 2015.

composition $^{3}$ (FIGURE 1), which together represent the basis of technical, physical and artistic preparation of RG athletes ${ }^{18}$. 

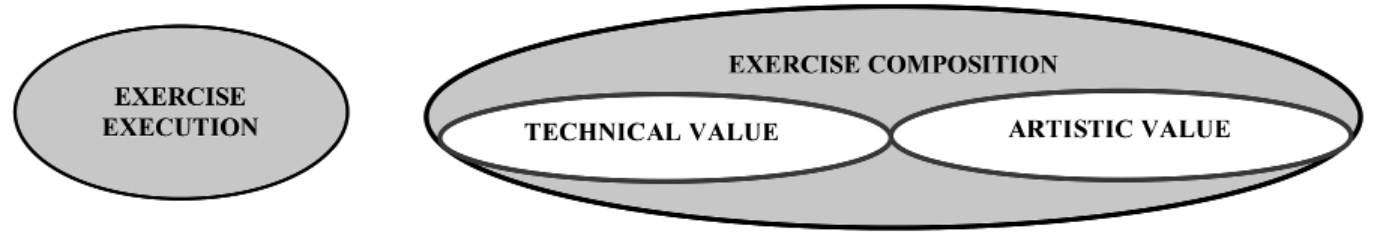

FIGURE 1 - Specific requirements for composition and execution in $\mathrm{RG}^{19}$.

This research focuses on the artistic aspects of rhythmic gymnastics routines, deflagrated in the $\mathrm{CP}$ as belonging to the "Artistic Value (AV)". The AV received prominence as a specific item in the RGCP in $2001^{5}$, comprising the music and routine analysis ("basic composition" - BC - and the "particular artistic features" - CAP), a format that remains until the later RGCP (2009-2012).

Understanding the RGCP and its relation to the "AV" routines implies expanding the search of understanding to the issues related to jury composition, gymnast dresscode, the importance of music/musical accompaniment in this sport, questions related to the composition in general, and to the body and pre-acrobatic elements. Finally, understanding how these aspects are tied to the generalities of the artistic composition of a $\mathrm{RG}$ routine.

Eight Olympic cycles of the RGCP were analyzed and subsequently separated into two categories or main stages. The first stage covers the first three Olympic cycles (1985-1988; 1989-1992; and 1993-1996), and has the presence of individual competitions at the Olympic Games (OG). The second stage covers the other cycles (1997-2000; 2001-2004; 2005-2008; 2009-2012; and 2013-2016) and has the participation of individual gymnasts and as well as groups in OG.

\section{The first stage}

In this first stage, the choreographic compositions (CC) were marked by the presence of a musician (usually a pianist) who accompanied the routines. The routines were performed in $12 \times 12$ meter areas, and had as a basic feature the alternation of fast and slow passages, and the use of motion fluency (1985-1988; 1989-1992 cycles).

Although this modality is connected to dance, mentions of folklore, elements of classical and modern dance and jazz elements were not allowed, as it was considered indispensable that the gymnastic routine respect the sportive character of the modality. As for the gymnast's atire (leotard), it had to be discrete, with few details and no exposure of the gymnast's back or neck. The presence of flowers, sequins, or any other items that highlighted the leotard were not allowed. The use of tights, to the ankle, was allowed from the 1993-1996 cycle onwards.

In this first stage, the scores of the routine reached a maximum of ten points. The judge board was formed earlier by a jury of four judges and a chief judge (19851988), six judges and a chief judge (1989-1992) and eight referees and a chief judge (1993-1996). This last cycle introduced a division into jury of execution and jury of composition. Each one was responsible for evaluating specific issues of the routine. This division resulted in a more rigorous evaluation of the routines as it has a high number of judges (1989-1992), and the division by specialties (1993-1996).

The routine composition is initially guided by the item that deals with Generalities (individual and group). For all cycles, the body elements of RG include jump, balance, turns/pivots, waves/ flexibilities, difficulty elements, a situation that remains until the 2009-2012 cycle. For the 6th cycle, there is a requirement that the routine be based on the temperament of the gymnast, the pace and character of the music chosen. This should demonstrate coordination elements, flexibility and the dynamic relationship between the gymnast and the apparatus. The next cycle (1989-1992) added the diversification of body and apparatus elements, as well as the use of different trajectories, levels and forms of displacement. This cycle introduced the risk element (element with loss of visual contact with the apparatus).

The last cycle of this first stage showed, for the first time, information about 'background music', highlighting the importance of connection and unity between the gymnast and the music. The risk elements became more demanding, adding rotational elements in its execution. The body and facial expressions emerged as important features of choreographic compositions, a situation addressed by RGCP as a chance to express themselves through movement. However, it is important to highlight the barring of circus questions, since theatrical expressions were and are considered inappropriate in this modality. 
RG contemplates pre-acrobatic elements into its routines from the first $\mathrm{CP}$, an approach notable of the gymnastic character, as well as the distancing from modalities such as artistic gymnastics (elements with flight are not allowed). In the first stage analyses, the only elements allowed were the rolls (forward, back and side), passages supports by hand (one or two), forearm, chest and shoulders. Despite the continuous reinforcement on the importance of the relationship between music and motion in RG, the first stage $\mathrm{CP}$ showed an increase in number of body difficulty elements along the Olympic cycles. In the 6th cycle (1985-1988), the gymnast had to carry out eight difficulties, which were divided into upper (two) and medium (six). The routine required balanced distribution in the composition. The next cycle continued to require eight difficulties, but now with four upper and four medium. The 8th cycle (1993-1996), brought a division into Fundamental group difficulties (jumps, pivots, balance and flexibility/waves) and Other groups (displacements, hops, balancing etc.). Here, there was also the leveling of body difficulties (A, B, C and D), and an increase of body difficulties number to 12 .
As for the difficulties, the 6th cycle describes the body difficulties in a table form, and has an average amount of 42 execution possibilities (from the body groups). The next cycle already provides illustrations of the body elements, showing 69 options of body difficulties. These illustrations were improved in the 8th cycle (1993-1996) over the 80 options of body elements described by the CP. In addition to the body difficulties, the RGCP also features a basic description of the handling possibilities of the apparatus, which must be performed in a different and original way.

This first stage of the research revealed, thus, an attempt by Rhythmic Gymnastics at maintaining its roots and advance the search for new elements and conditions. The addition of body elements to the $\mathrm{CP}$, as well as the increasing of the number of difficulties present in the routines, represent a search for sportivization and standardization of the modality. The arrival of rules and guidelines would make (at first) RG less subjective, but still full of grace and plasticity.

TABLE 3 tries to resume all the important information of the RGCP in this first stage, bringing considerations about aspects related to music, jury, routines, artistic aspects and body difficulty.

TABLE 3 - Major changes in artistic and technical value from the 6th to 8th CP cycle.

\begin{tabular}{|c|c|c|}
\hline Cycle & Artistic value & Technical value \\
\hline 1985-1989 / 1989-1992 & $\begin{array}{l}\text { The music that previously could only be } \\
\text { orchestrated or played live. }\end{array}$ & $\begin{array}{l}8 \text { difficulties in each routine, leveled at } \\
\text { middle and upper }\end{array}$ \\
\hline \multirow[t]{3}{*}{ 1993-1996 } & $\begin{array}{l}\text { Music can now be mixed with the use } \\
\text { of more instruments, encompassing } \\
\text { different styles and rhythms. }\end{array}$ & $\begin{array}{l}12 \text { difficulties in each routine, leveled } \\
\text { from } A(0,10) \text { to } D(0,40) \text {. }\end{array}$ \\
\hline & $\begin{array}{l}\text { Music can not be used as "background } \\
\text { music" and a relationship between music } \\
\text { and movement becames requires }\end{array}$ & $\begin{array}{l}80 \text { possibilities exercises (as there were } 42 \\
\text { in the cycle from } 1985 \text { to } 1988 \text {, and } 69 \text { in } \\
\text { the cycle } 1989-1992 \text { ) }\end{array}$ \\
\hline & $\begin{array}{l}\text { Greater expressiveness is requested, and } \\
\text { a relationship with the interpretation of } \\
\text { the music. }\end{array}$ & \\
\hline
\end{tabular}

\section{The second stage}

The second stage of the research includes the 9th to the 13th CP cycles, thus a period of time from 1997 to 2015 (considering that the last cycle finishes in 2016).
To reduce subjectivity ${ }^{20-22}$, this stage is marked by onset/introduction of evaluation forms of the routines (individuals and groups). This form must be submitted to the judge board at the beginning of each event and must contain a description of the composition (apparatus and body/difficulties elements) in the routine execution order. 


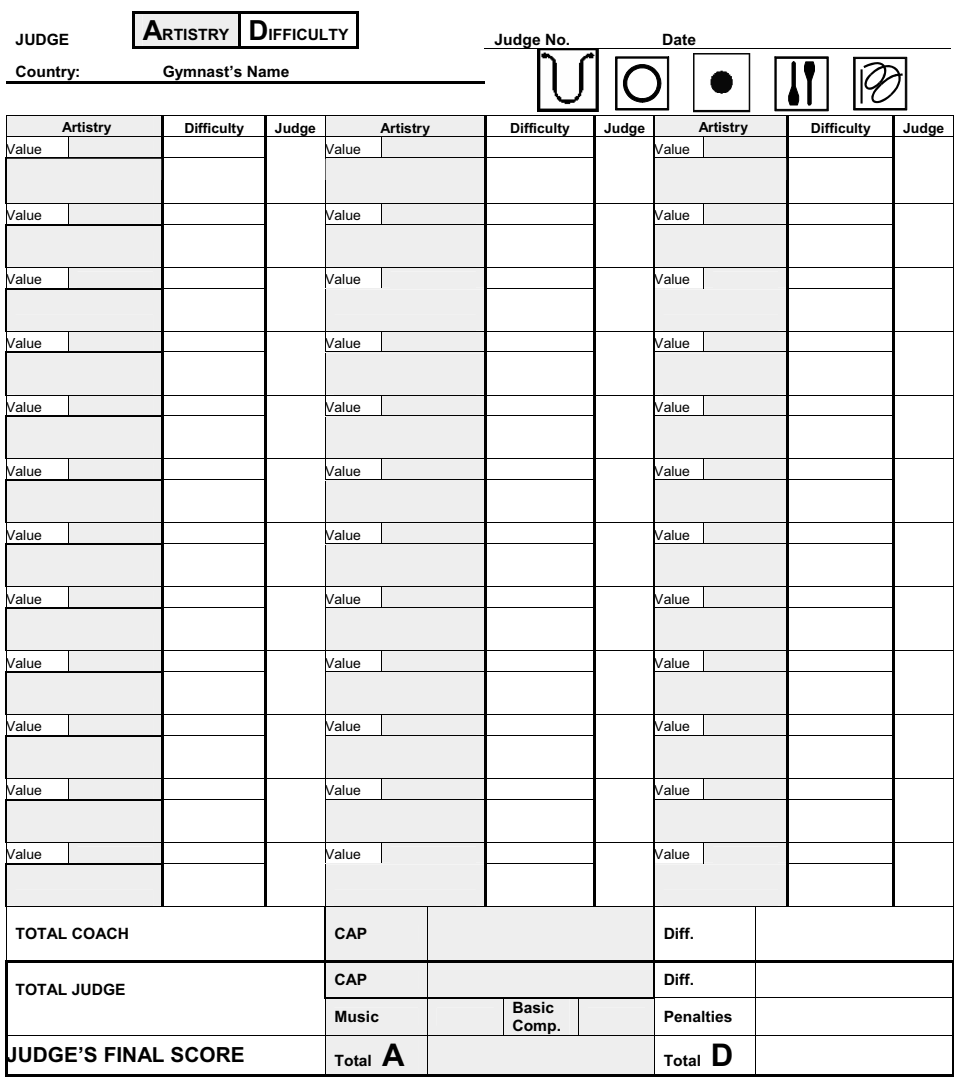

Coach's signature....................

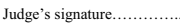

FIGURE 2 - Example of routine form proposed in the 9th CP cycle (2005-2008) ${ }^{23}$.

This stage of the research begins with the 9th CP cycle (1997-2000), and includes practically the same requirements brought by the previous cycle (1993-1996). The previous division of the judge board remained, organized into composition (technical and artistic) and execution juries. The requirements for the atire became softer, now the use of colored leotards, geometric designs and flowers is allowed. The body difficulties remain divided into Fundamental group and Other groups (connecting elements), and leveling continues to utilize the concepts from A ( 0,10 points) to $\mathrm{D}$ ( 0,40 points). This RGCP version introduced tables with handling apparatus possibilities, since the 12 body difficulties must necessarily be linked to the handling of apparatus. Moreover, despite the continuity in the difficulties being classified as A and $\mathrm{D}$, the code brought an increase from 11 to 24 flexibility difficulties ${ }^{24}$.

The next cycle analysed, the 10th (2001-2004) ${ }^{25}$, could be considered the first portrait of contemporary RG. Endorsed by the elaboration of a choreographic evaluation form, previously drawn up by technicians, this cycle is designed to perform correct movements, which meet the $\mathrm{CP}$ requirements.

As in the previous cycle, this one presented the requirement of the Compulsory Body Group (CBG) for each apparatus (FIGURE 3). The routine should include at least five difficulties of the minimum of 10 (maximum 12) ${ }^{25}$. 


\begin{tabular}{|c|c|c|c|c|}
\hline ROPE & HOOP & BALL & CLUBS & RIBBON \\
\hline Jumps/Leaps & ( & 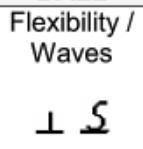 & $\begin{array}{c}\text { Balance } \\
\mathbf{T}\end{array}$ & $\begin{array}{c}\text { Pivots } \\
\text { d }\end{array}$ \\
\hline
\end{tabular}

FIGURE 3- Compulsory body groups movement on each apparatus in the 10th, 11th and 12th CP cycle.

The difficulties in this $\mathrm{CP}$ were leveled from A (0.10) to E (0.50), and arranged to provide an average of 28 types of jumps, 19 options of balances, 25 types and combinations of pivots and 30 kinds of flexibilities/waves, totaling 102 types of elements (with two or more variations) ${ }^{25}$.

In all previous RGCP, the flexibility/waves group had on average ten types of elements, and the present $\mathrm{CP}$ innovated by bringing 30 kinds of possibilities. Such condition was easily verified in routines, which now include extreme flexibility elements ${ }^{26}$ and low apparatus handling. Despite the attempt of the document to organize and systematize the possibilities of working with the apparatus, the training in this period was focused on acquisition and development of range of joint flexibility (physical capacity) ${ }^{26-27}$, to the detriment of artistic issues and apparatus handling.

In this $\mathrm{CP}$, the jury were divided into three groups: execution (E), artistic (A) and difficulty (D), and the highest score could reach 30 points. In contrast to the scenario, the FIG brought the AV of the routines to the foreground, from the moment it indicates the music and routine analysis $(\mathrm{BC} \text { and the } \mathrm{CAP})^{25}$.

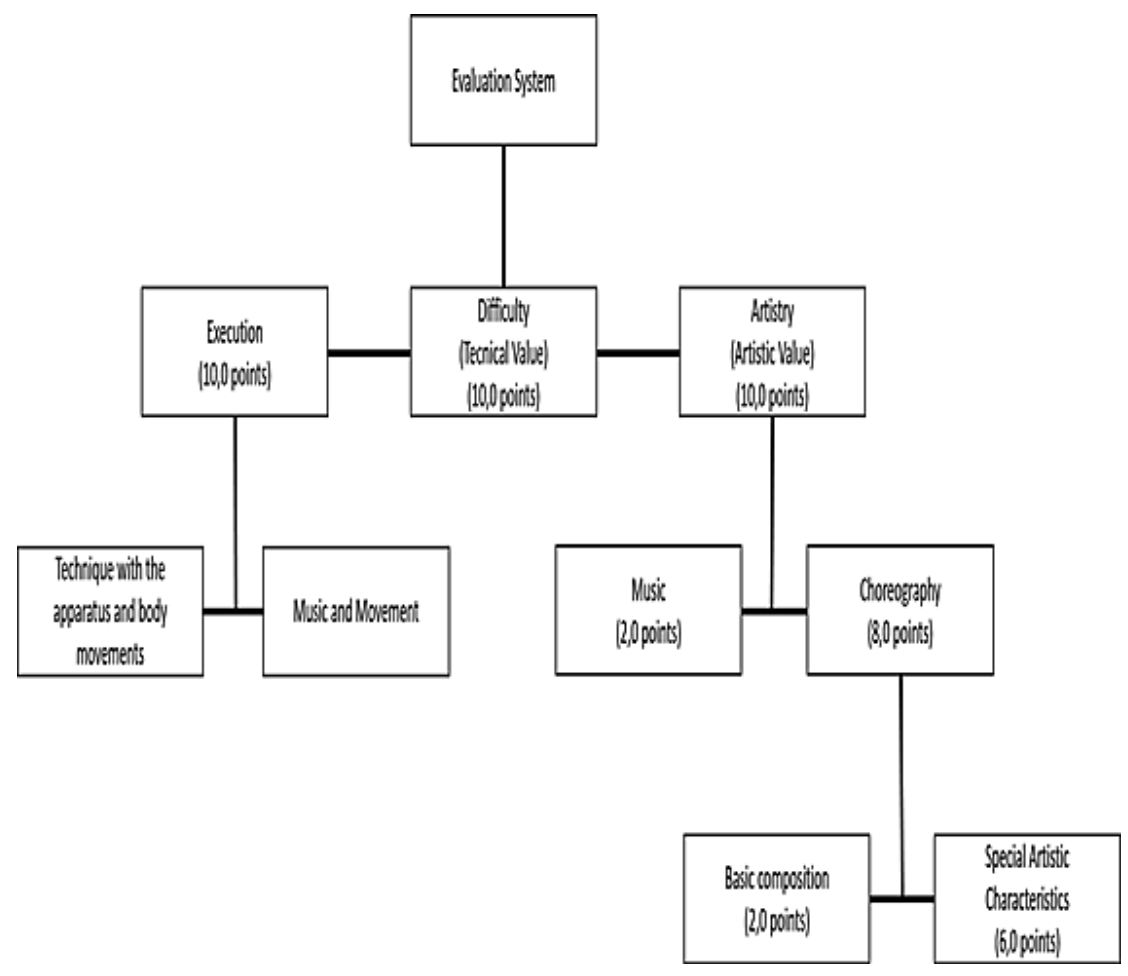

FIGURE 4 - Organization chart from the evaluation system of the 10th CP cycle (2001-2004) ${ }^{25}$

In the 11th cycle (2005-2008), there was an increase of technical requirements for the number of difficulties (now 18 body difficulties per gymnast) ${ }^{19}$, these being leveled from A (0.10) to J (1.00) or more. This scenario reaffirms the one presented by the previous cycle in which the execution of body elements of high values and high degree of difficulty are as or more important than the composition and its guiding idea ${ }^{19}$. The attire also passed through changes, beyond colors being treated more permissively, the use of skirts (short length - to the pelvic region) are also released in order to embellish the presentations.

In this $\mathrm{CP}$, the jury is still divided into three groups: execution (E), artistic (A) and difficulty (D), however the score is now based on the sum of the composition $(\mathrm{A}+\mathrm{D} / 2)$ and execution totaling 20 points. Again, in contrast to the appreciation scenario 
of body elements, FIG reaffirms the importance of the artistic component in RG routines.

With the judge board being divided into three groups of evaluation, it was necessary that the 11th CP (2005-2008) bring a clarification of each one. The execution continued with the instructions on the penalties regarding the technical faults (body and unit) and mistakes between music and movement (loss of pace or lack of harmony). The difficulties were still divided into Fundamental groups and Other groups. The increase from 12 to 18 body difficulties in each composition also resulted in increased element possibilities for each body group $^{28}$, situation that is easily observed by 183 elements presented in CP Tables (47 jumps/leaps, 46 balances, 52 pivots and 38 flexibilities/waves).

The Artistic Value, now more detailed, provided information about the music ( 1,0 point), which may be interpreted by one or several instruments, including the voice used as an instrument (without words), and choreography ( 9,0 points). Still important for the routine composition was the strict harmony between the character and the rhythm of the music through the exercise and its movements. The choreography is characterized by a guiding idea performed, from beginning to end, and is divided into basic composition ( 2,0 points): which included the choice of body and apparatus elements, balance between right and left hand, acrobatic elements and variety of the choreography; and CAP (7,0 points). The CAP included the uses and mastery of the apparatus, and the originality of the composition.

In this situation, a reflection about the artistic issues becomes necessary:

On the one hand, the artistic value is the part of code that looks more favorably at aesthetics and beauty of RG, on the other, technical merit seems to be the part that can stifle them. The growing demand on the amount and complexity of body and apparatus movements makes the gymnast (and their coaches) bother to comply with all the technical requirements to the detriment of artistic matters (lower value). Daisy Barros, one of the first judges in Brazil, commented on it in a scientific event SIGARC: "Today, the RG performances looks like a cat running after the mouse, the gymnast after the apparatus... Increasingly, RG distances itself from the art" ${ }^{\text {"11 }}$.

The 12th cycle (2009-2012) ${ }^{29}$ introduced some significant changes for a return of the sport to its origins. The flexibility difficulties characterized as a very important technical element were reconsidered in this cycle once the degree of amplitude no longer comprises difficulty.

The CP 2009-2012 29 presented a new organization of the judge board and in the way of evaluating the sport, adding to the criterion an evaluation of the body (D1) and apparatus elements (D2), together with executition (E) and artistic (A) juries. The 183 choices of body difficulties remain, but return from 18 to 12 (with values between $\mathrm{A}(0,10)$ and J $(1,00)$ or more) in each composition. This change provided more time for artwork and guiding idea development in the routine, which imposes a connection between the music and movement, harmony and expressivity ${ }^{19}$. Facial expression and music interpretation took a special place in this new version of the CP.

Risk elements return to this version of the CP, and they could be executed with or without throws, bringing to the choreography the excitement of imminent "loss of apparatus". Another new possibility that arises in this $\mathrm{CP}$ is mastery with and without throws. In this new condition, mastery without throws must be performed, among other situations, with a technical element of the apparatus, coupled to a body difficulty, without the help of hands, without visual control or during a sequence of rhythmic steps. The sequence of rhythmic steps must submit a variation of the apparatus work (moving in differents planes, direction and level).

The evaluation of the artistic component obtained a very important character, as it acquires an evaluation form and specific guidelines (FIGURE 3). The main objective of the artistic component is to bring emotion and the idea of expression, both translated through the following three aspects: the musical accompaniment, plastic artistic image and expressivity. 


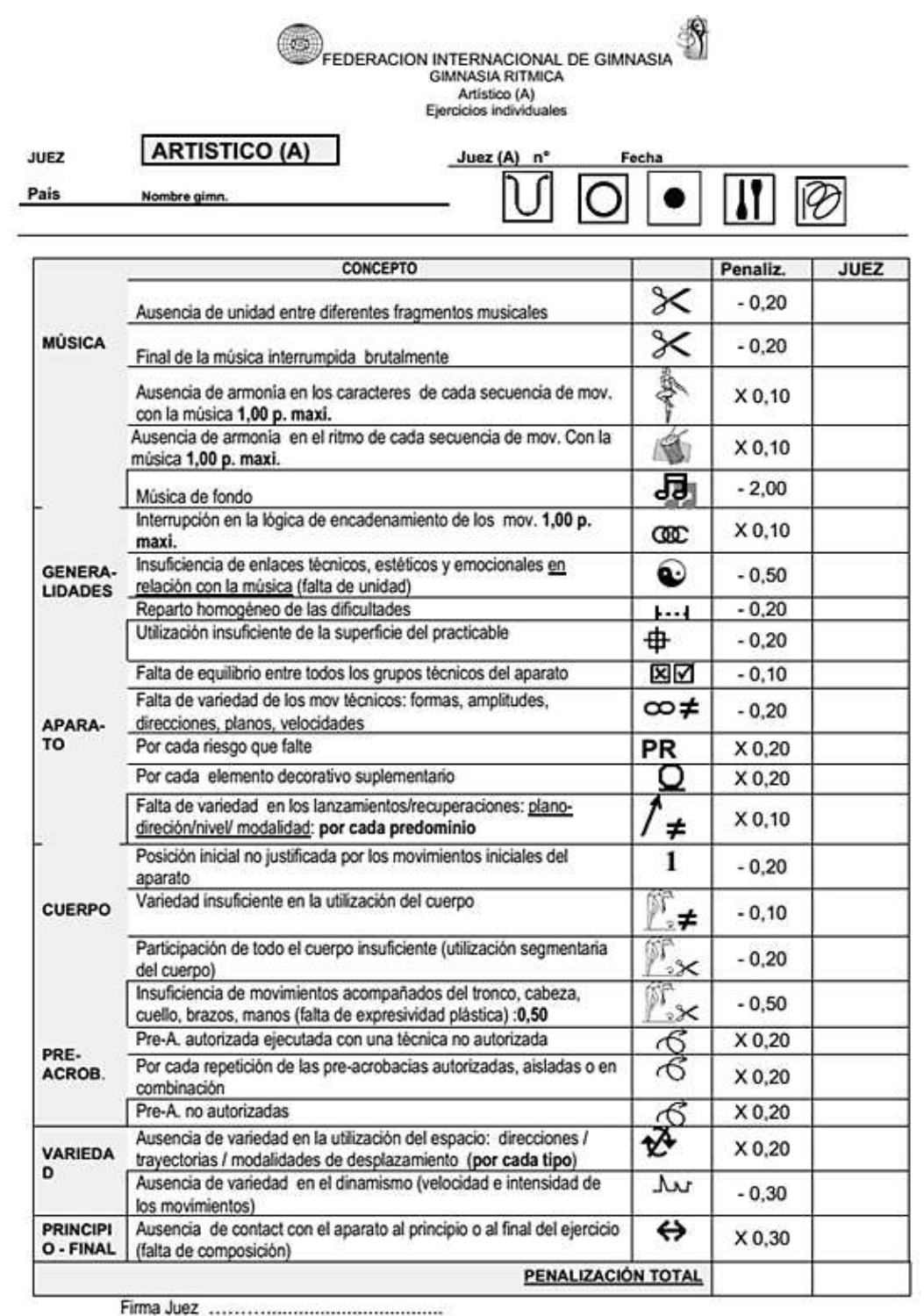

FIGURE 5 - Evaluation form for artistic component proposed in the 12th CP cycle (2009-2012) ${ }^{29}$.

The fifth and last Olympic cycle (2013-2016) is still in place. In this, the judge board returned to evaluate difficulty (D) and execution (E). The evaluation of the artistic issues (unity of composition, music and movement, body expression and use of space) of the routine became the responsibility of the execution jury. The evaluation form of artistic issues loses its usefulness.

In this last cycle, the music can be interpreted by one or several instruments or a musician, including the voice used as an instrument. The use of voice and words is only permitted by one of the individual gymnasts or group routines. Body expression called for the participation of all body segments in movement, and together with the facial expression, should communicate the theme of the music and the message of the routine composition ${ }^{10}$.

In the fifth cycle, the difficulty consists in four important big groups (FIGURE 6). The number of difficulties suffers a significant reduction (minimum six and maximum nine), however the need that they be coordinated with the handling of the apparatus holds. In this version, the body difficulties are reviewed, resulting in a decrease in their values, maintaing only the terms from $\mathrm{A}(0.10)$ to $\mathrm{E}(0.50)$, and deleting the body group of flexibility/waves. In this this cycle, this is embedded through balance and pivot groups, causing a reduction to 27 choices of body difficulties (in addition to its variations). The risk elements, or dynamic elements with rotation and throw $\left(\mathbf{R}^{t} \mid\right)$, are 
Toledo E \& Antualpa K.

regulated as to their amount (two or more rotations), and adding some complex criteria execution.

Two other new groups emerged as integral components of difficulty in this edition of the $\mathrm{CP}$ : apparatus mastery and dance step combinations. Both groups bring us a new comprehension about $\mathrm{RG}$, as they try to refound the beauty and magic of this sport.

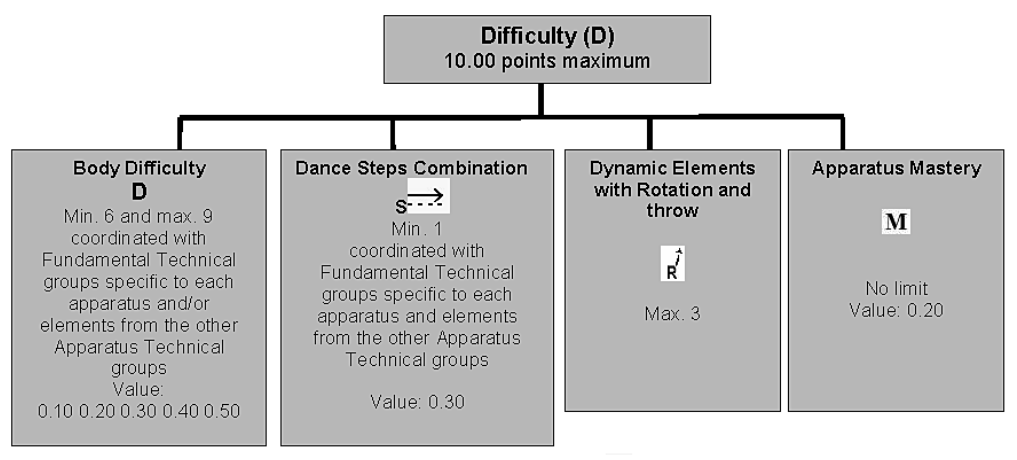

FIGURE 6 - Difficulty exigencies: Code of Points 2013-2016 ${ }^{10}$.

Apparatus mastery (M) is responsible for nonordinary combinations of apparatus elements and brings innovation and surprise to choreography. Dance step combinations $(\vec{\overrightarrow{ }} \overrightarrow{\text { ) }}$ ) (ballroom, folklore, modern dance, etc.) must show different rhythmical patterns with the apparatus in motion during the entire combination and be performed during a minimum of eight seconds in accordance with the tempo and rhythm of the music.

All of these conditions aimed at reclaiming/bringing back the artistic value, in perspective to innovative character of the sport, as they now have an equal or greater importance than the physical necessities and body difficulties, once so valued by the scoring code.

TABLE 4 - Major changes related to artistic and technical value from the 9 th to the $13^{\text {th }} \mathrm{CP}$ (second stage).

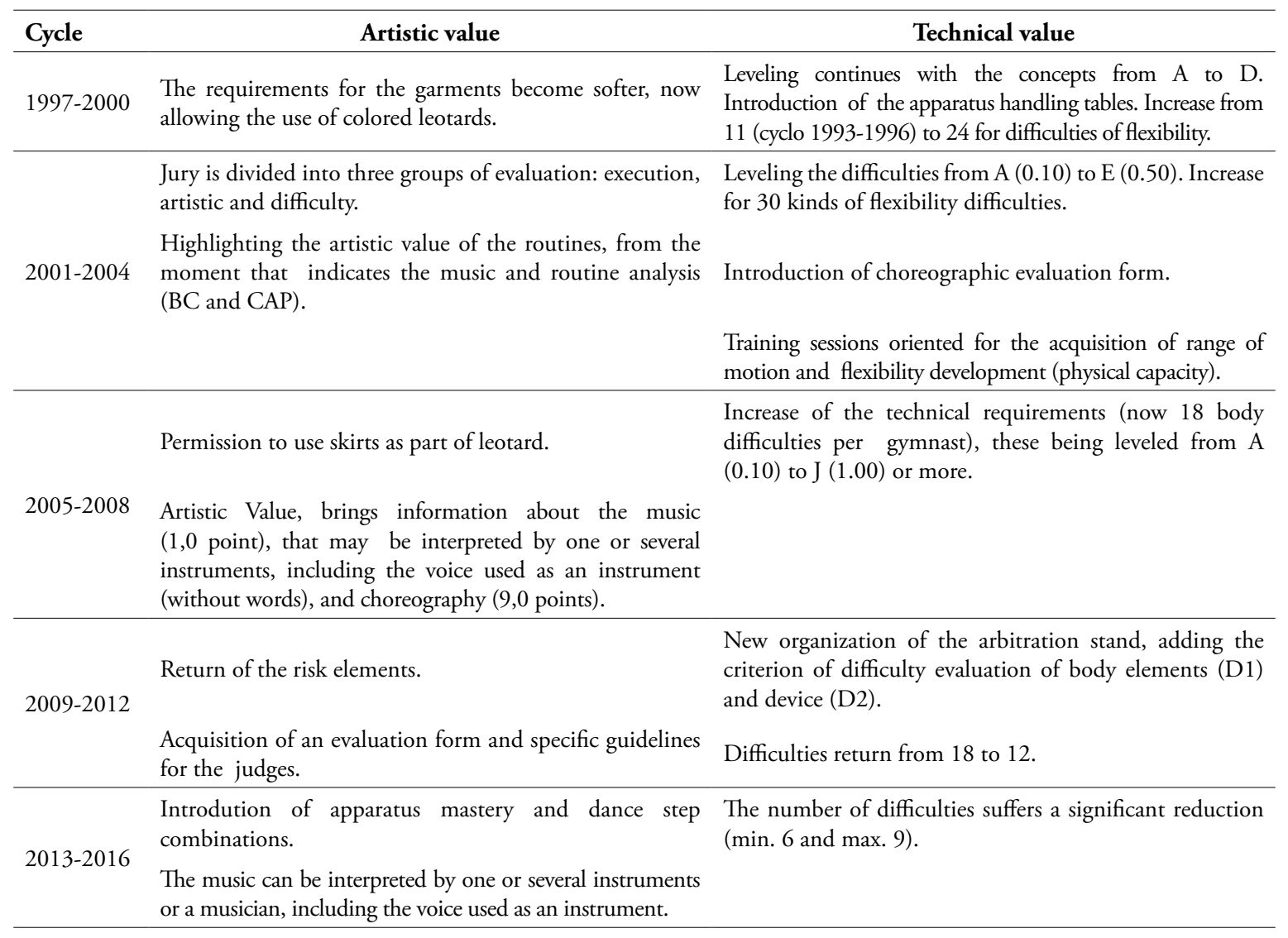


In general, there is an increase in the appreciation of the AV component of the routines, going back to what had already been signaled in the literature: In RG, development increases the role of the aesthetic component. We can consider the aesthetic principle of rhythmic gymnastics not only as a complementary element, but as a basic element of discipline structure that directly affects the formation of sports results. Sports technique and perfection constitute, to a considerable degree, the realization of the aesthetic program. The aesthetic value of the movements must be an object of special concern to the coach and athlete ${ }^{30}$.

In the analysis of the three decades of the Code of Points of Rhythmic Gymnastics, it was possible to outline how the artistic aspect was being constituted in this document, triggering ruptures and continuities (properly marked above).

As relates to artistic aspects, it was possible to confirm the previous hypothesis of this study, that in the last RGCP (second stage) this aspect has undergone few changes.

The promoting of the artistic aspects of RG in the new RGCP meets the origins of the sport. Such condition shows the manifestations of rhythmic and dance, as major influences of the artistic character of this sport. An aspect that has been valued in the teaching of the sport, by some authors in contemporary times, such as Toledo ${ }^{11,31}$, VIDAL ${ }^{32}$, Marquez $^{33}$ and others.

The current Code of Points (2013-2016) can be regarded as a cycle, which marks the sport's story by two aspects: the permissiveness of routines with singing (which, since the creation the RGCP, has not been allowed) and significant changes in the appreciation of the artistic aspects of the routines.

Thus, the study contemplated a gap in scientific inquiryin analyzing the RGCP not only in its historical aspect, but also and especially its artistic component. But others still deserve the academicscientific tract.

\section{Resumo}

A valorização dos aspectos artísticos do Código de Pontuação na ginástica rítmica: uma análise das últimas três décadas

Em busca de melhor promover os aspectos artísticos, tendo-se em vista os últimos ciclos olímpicos, 0 atual Código de Pontuação de Ginástica Rítmica (CPGR) foi submetido a significativas mudanças. É a partir desse contexto que essa pesquisa, de caráter documental e histórico, se desenvolve, tendo como objetivo, analisar as mudanças nos últimos oito ciclos Olímpicos de CPGR (1985-2016), com foco nos aspectos artísticos da modalidade. A partir da análise de diferentes ciclos do CPGR, conclui-se que há conexões de interdependência entre os aspectos artísticos e os técnicos, sendo nítido que quando há uma supervalorização do aspecto técnico há uma desvalorização do artístico. Foi possivel identificar fases do CPGR, e portanto, da modalidade. Apesar de manter as suas raízes artísticas (de Dança e Ritmo), a busca pela esportivização e sistematização da modalidade, trouxe uma primeira fase caracterizada pela busca do caráter esportivo e pela padronização dos gestos da GR, baseada na inclusão de novos elementos do corpo no CPGR. A segunda fase se caracteriza por uma retomada do aspecto artístico, confirmando nossa hipótese sobre a grande mudança do último CPGR. Constatamos de maneira geral, que o CPGR atual retoma a relação entre a GR e suas origens, influenciado pela Ginástica Estética (sueca), Rítmica e Dança. Tal condição é observada, uma vez que o atual Código de Pontuação (2013-2016) marca a história da modalidade por dois aspectos: a permissão de rotinas com canto, que não eram permitidas desde a criação do CPGR; e mudanças significativas para a valorização de aspectos artísticos dos rotinas.

Palavras-Chave: Estética; Artístico; Técnica; Composição; Ginástica; Coreografia. 


\section{References}

1. Langlade A, Langlade NR. Teoria general de la gimnasia. Buenos Aires: Editorial Stadium; 1970.

2. Bodo-Schmid A. A Gimnasia ritmica deportiva. Barcelona: Editorial Hispano Europea; 1985.

3. Bobo M, Sierra E. Ximnasia rítmica deportiva- adestramento e competición. Santiago de Compostela: Lea; 1998.

4. Toledo E. Fundamentos da ginástica rítmica. In: Nunomura M, Tsukamoto MH, organizadoras. Fundamentos das ginásticas. Jundiaí: Fontoura; 2009.

5. Hobsbawn E, Ranger T. A invenção das tradições. 4a ed. Rio de Janeiro: Paz e Terra; 2006.

6. Bracht V. Sociologia crítica do esporte: uma introdução. 3a ed. Ijuí: Unijuí; 2005.

7. Elias N, Dunning E. A busca da excitação. Lisboa: Memória e Sociedade; 1992.

8. Fédération Internationale de Gymnastique. Rules disciplines. Lausanne: FIG; 2014. Available from: http://www.figgymnastics.com/site/page/view?id=375.

9. Lourenço MRA. O insconstante código de pontuação na ginástica rítmica. In: Paoliello E, Toledo E, organizadores. Possibilidades da ginástica rítmica. Barueri: Phorte; 2010.

10. Fédération Internationale de Gymnastique. Code of points: rhythmic gymnastic 2009. Lausanne: FIG; 2013. p.1-70. Available from: http://www.fedintgym.com/rules/files/rg/RG CoP 2013-2016 (English) Feb 2013.pdf.

11. Toledo E. Estética e beleza na ginástica rítmica. In: Nunomura M, Tsukamoto MH, organizadoras. Fundamentos das Ginásticas. Barueri: Phorte; 2010. p.19-44.

12. Velardi M. Ginástica rítmica: a necessidade de novos modelos pedagógicos. Campinas: Papirus; 1999.

13. Laffranchi B. Planejamento, aplicação e controle da preparação técnica na ginástica rítmica: análise do rendimento técnico alcançado nas temporadas de competição. Porto: Universidade do Porto; 2005.

14. Aviles MI, Díaz YG, Borrás NO. Reflexions on planning and control of sport training in rhythmic gymnastics. In: Schiavon LM, Heinen T, Bortoleto MAC, Nunomura M, Toledo E, organizadores. High performance gymnastic. Herzogenrath: Shaker; 2014. p.177-194.

15. Govea Y. Metodología para el control de la intensidad del entrenamiento de los ejercicios competitivos individuales en gimnastas élites cubanas de gimnasia rítmica. La Habana: Universidad de Ciencias de la Cultura Física y el Deporte Manuel Fajardo; 2011.

16. Lakatos EM, Marconi M. Fundamentos de metodologia científica. 5a ed. São Paulo: Atlas; 2003.

17. Gimnica.com.br [homepage na Internet]. Gimnica: biblioteca virtual de Ginástica. Eliana de Toledo; 2015. Disponível em: http://www.gimnica.com.br/.

18. Antualpa KF. Centros de treinamento de ginástica rítmica no Brasil: estrutura e programas [dissertação]. Campinas(SP): Universidade Estadual de Campinas; 2011.

19. Manos M, Propescu L. The impact induced by the 2009-2012 FIG Code of Points on artistic compositions in rhythmic gymnastics group events. Procedia Soc Behav Sci. 2014;117:300-6.

20. Flessas K, Mylonas D, Panagiotaropoulou G, et al. Judging the judges' performance in rhythmic gymnastics. Med Sci Sport Exerc. 2015;47(3):640-8.

21. Fernandez-Villarino M, Bobo-Arce M, Sierra-Palmeiro E. Practical skills of rhythmic gymnastics judges. J Hum Kinet. 2013;39:243-9.

22. Babiloni C, Del Percio C, Rossini PM, et al. Judgment of actions in experts: a high-resolution EEG study in elite athletes. Neuroimage. 2009;45:512-21.

23. Fédération Internationale de Gymnastique. Code of points: rhythmic gymnastic 2005. Lausanne: FIG; 2007. Available from: http://www.japan-rg.com/lineup/event/page/competiton/child12/item/coderg0701-e2.pdf.

24. Boligon L, Silva SLPO, Barbosa-Rinaldi IP. As alteraçôes do elemento flexibilidade no código de pontuação de ginástica rítmica entre 1984 e 2012. Lect Educ Fis Deportes. 2011;16.

25. Fédération Internationale de Gymnastique. Code of points: rhythmic gymnastic 2001-2004. Lausanne: FIG; 2001.

26. Douda HT, Toubekis AG, Avloniti AA, Tokmakidis SP. Physiological and anthropometric determinants of rhythmic gymnastics performance. Int J Sports Physiol Perform. 2008;3:41-54.

27. Bobo-Arce M, Méndez-Rial B. Determinants of competitive performance in rhythmic gymnastics. a review. J Hum Sport Exerc. 2013;8:711-27.

28. Ávila-Carvalho L, Klentrou P, Lebre E. Handling, throws, catches and collaborations in elite group rhythmic gymnastics. Sci Gymnast J. 2012;4:37-48.

29. Fédération Internationale de Gymnastique. Code of points: Rhythmic Gymnastic 2009. Lausanne: FIG; 2009. Available from: http://www.rsgbul.info/coderg0912-e.pdf. 
30. Lisitskaya T. Preparación coreográfica. In: Gimnasia rítmica: deporte \& entrenamiento. Barcelona: Paidotribo; 1995. p.39-64.

31. Toledo E. Aspectos pedagógicos do ensino da ginástica rítmica e os princípios da pedagogia da autonomia. In: Nista-Piccolo VL, Toledo E, organizadoras. Abordagens pedagógicas do esporte. Campinas: Papirus; 2014. p.97-115.

32. Vidal A. La dimensión artística de la gimnasia rítmica deportiva: análisis del conjunto como acontecimento coreográfico. Vigo: Universidad de Vigo; 1997.

33. Márquez M. Especialización de los jueces en la gimnasia rítmica: dificuldad, artístico, ejecución: una tendência? Seminário Internacional de Ginástica Artística e Rítmica de Competição; 19-20 jul. 2007; Campinas, BR. Campinas: FEF/UNICAMP; 2007.

\begin{tabular}{r|r} 
ENDEREço & Eliana de Toledo \\
Curso de Ciências do Esporte & Recebido para publicação: 23/10/2015 \\
Faculdade de Ciências Aplicadas & Aceito: 11/12/2015 \\
Universidade Estadual de Campinas & \\
R. Pedro Zaccaria, 1300 - Campus Limeira & \\
13484-350 - Limeira - SP - BRASIL & \\
e-mail: eliana.toledo@fca.unicamp.br &
\end{tabular}

